Laidlaw, R. A., J. Smart, M. A. Smart, T. W. Bodey, T. Coledale, and J. A. Gill. 2019. Foxes, voles, and waders: drivers of predator activity in wet grassland landscapes. Avian Conservation and Ecology 14(2):4. https://doi.org/10.5751/ACE-01414-140204

Copyright (C) 2019 by the author(s). Published here under license by the Resilience Alliance.

Research Paper

\title{
Foxes, voles, and waders: drivers of predator activity in wet grassland landscapes
}

\author{
Rebecca A. Laidlaw ${ }^{1}$, Jennifer Smart ${ }^{1,2}$, Mark A. Smart ${ }^{3}$, Thomas W. Bodey ${ }^{2,4}$, Tessa Coledale ${ }^{5}$ and Jennifer A. Gill ${ }^{1}$ \\ ${ }^{1}$ School of Biological Sciences, University of East Anglia, Norwich Research Park, Norwich, UK, ${ }^{2}$ RSPB Centre for Conservation \\ Science, Royal Society for the Protection of Birds, The Lodge, Sandy, UK, ${ }^{3}$ Royal Society for the Protection of Birds, The Lodge, \\ Sandy, UK, ${ }^{4}$ Environment \& Sustainability Institute, University of Exeter Penryn Campus, Penryn, UK, ${ }^{5}$ Royal Society for the \\ Protection of Birds, Scotland Headquarters, Edinburgh, UK
}

\begin{abstract}
Impacts of generalist predators on declining prey populations are a major conservation issue, but management of this situation is constrained by limited knowledge of the factors influencing predator distribution and activity. In many declining populations of ground-nesting waders, high levels of nest and chick predation are preventing population recovery. Red foxes, Vulpes vulpes, are the main predator but their primary prey is small mammals. On wet grasslands managed for breeding waders, small mammals are concentrated in tall vegetation outside of fields, and nests closer to these patches are less likely to be predated. To assess whether these patterns result from fox attraction to small mammals, and thus the potential for management of tall vegetation to influence nest predation rates, we quantify seasonal and spatial variation in fox and small mammal activity in relation to tall vegetation patches. Across wet grassland sites, tall vegetation patches of any size $(>0.05$ ha) supported small mammals and small mammal activity increased throughout the wader breeding season, while the use of fox track plots within fields declined seasonally. Although within field fox track plot use did not vary with distance to tall vegetation, over the 1064 nights of trail camera recording, foxes were seen in areas with tall vegetation on 13 nights compared with short vegetation on only two nights. These findings suggest that lower predation rates of Lapwing, Vanellus vanellus, nests close to tall vegetation could reflect fox attraction to areas with small mammal activity, but any such effects would primarily operate later in the breeding season, and may therefore primarily influence late nests and chicks.
\end{abstract}

\section{Renards, campagnols, et échassiers : les prédateurs les plus actifs dans les prairies humides}

RÉSUMÉ. L'impact des prédateurs généralistes sur le déclin des populations de proies constitue un problème majeur en termes de conservation. Toutefois, la gestion de ce problème est entravée par des connaissances limitées quant aux facteurs qui influencent la répartition et l'activité des prédateurs. Dans de nombreuses populations déclinantes d'échassiers à nidification terrestre, un niveau élevé de prédation des nids et des petits empêche la reprise de l'augmentation des populations. Le renard roux, Vulpes vulpes, est le principal prédateur, mais il se nourrit essentiellement de petits mammifères. Dans les prairies humides gérées pour les échassiers nidificateurs, les petits mammifères sont concentrés dans les hautes herbes qui bordent les champs et les nids les plus proches de ces espaces sont les moins susceptibles d'être attaqués. Pour savoir si ces modèles résultent de l'attirance du renard pour les petits mammifères, et par conséquent, pour estimer le potentiel de gestion de la végétation en vue d'influencer les taux de prédation des nids, nous quantifions les variations saisonnières et en termes de localisation par rapport à l'activité des renards et des petits mammifères en relation avec les zones de hautes herbes. Sur les sites de prairies humides, les zones de hautes herbes, quelle que soit leur taille ( $>0,05$ ha), les petits mammifères et leur activité ont augmenté tout au long de la saison de nidification des échassiers, tandis que les tracés de pistes de renards dans les champs déclinait de manière saisonnière. Même si les pistes de renards ne variaient pas selon leur distance par rapport à la haute végétation, au cours de 1064 nuits d'enregistrement par des caméras d'observation, des renards ont été aperçus dans des zones de haute végétation au cours de 13 nuits, alors qu'on n'en a vu que pendant deux nuits dans des espaces à végétation rase. Ces résultats suggèrent que des taux de prédation moindres des nids de vanneaux huppés, Vanellus vanellus, à proximité de hautes herbes pourraient refléter l'attrait du renard pour les zones d'activité de petits mammifères, mais ce type d'effet apparaîtrait principalement plus tard dans la saison de reproduction et pourrait par conséquent affecter les nids et les oisillons tardifs.

Key Words: habitat management; landscape management; predation pressure; shorebirds; sward structure

\section{INTRODUCTION}

Predator-prey relationships are key ecological interactions that are increasingly the focus of conservation management (Smith et al. 2010, Woodroffe and Redpath 2015, Marshall et al. 2016). The increasing impacts of generalist mesopredators following extirpation of apex predators (Ritchie and Johnson 2009, Colman et al. 2014) has resulted in an urgent need to identify conservation management strategies that can reduce these impacts (Bolton et al. 2007, Bodey et al. 2010, Laidlaw et al. 2017). Interactions between predators and their prey can potentially be influenced by key aspects of landscape and habitat structure (Alterio et al. 1998, Carter and Bright 2002, Gorini et al. 2012), particularly if

Address of Correspondent: Rebecca A. Laidlaw, School Of Biological Sciences, University Of East Anglia, Norwich Research Park,, Norwich,, United Kingdom, NR4 7TJ, r.laidlaw@uea.ac.uk 
these influence the distribution of other prey types that are not the subject of conservation concern (Laidlaw et al. 2013).

The combination of increasing predator impacts alongside habitat loss can be severely detrimental for many wild bird populations (Roos et al. 2018), with habitat degradation potentially facilitating increases in predation impacts (Thirgood et al. 2000, Evans 2004). For example, many wader populations in wetlands across Western Europe have declined severely as a consequence of the widespread loss and degradation of wetlands resulting from land drainage and agricultural intensification (Wilson et al. 2004). Consequently, populations of many bird species that breed in wetland habitats have become increasingly restricted to managed reserves and areas within agri-environment schemes (Ausden and Hirons 2002, Wilson et al. 2007, Smart et al. 2008, O'Brien and Wilson 2011). Efforts to improve wetland management within these areas, such as the maintenance of short swards and wet features, have been effective at attracting breeding waders (Smart et al. 2006, Eglington et al. 2008, 2010, Fisher et al. 2011). However, the impacts of predators of nests and chicks are severely constraining the recovery of these wader populations (Malpas et al. 2013, Roos et al. 2018), and most are continuing to decline (e.g., Hayhow et al. 2017).

A variety of management practices have already been undertaken to reduce the impact of predators on breeding waders on grasslands, including lethal control (Bolton et al. 2007), exclusion fencing (Rickenbach et al. 2011, Malpas et al. 2013), and habitat manipulation to reduce availability of predator breeding sites (Gibbons et al. 2007, Bodey et al. 2010). Predator removal or exclusion methods can be effective but can also be controversial, time- and resource-consuming, and often only have a temporary or local-scale influence on predator activity (Smith et al. 2010). However, understanding how predators and prey are distributed across these landscapes could aid identification of land management options to reduce predation impact on breeding waders.

On wet grasslands in Western Europe, evidence from nest cameras shows the red fox (Vulpes vulpes, hereafter referred to as foxes) to be the main predator of wader nests, accounting for $\sim 60 \%$ of recorded nest predation events across a range of studies (MacDonald and Bolton 2008). Foxes are a generalist predator whose varied diet predominantly comprises small mammals (Forman 2005, Dell'Arte et al. 2007). Small mammal distribution could thus be an important driver of fox activity and distribution, and the associated nest predation risk experienced by groundnesting birds. Breeding success of ground-nesting birds has also been linked to small mammal abundance (or a proxy of this measure) across a number of systems, e.g., periodicity in HighArctic wader breeding success as measured by proportion of juveniles in flocks; has been linked to lemming cycles (Summers and Underhill 1987, Aharon-Rotman et al. 2015); reduced productivity of arctic-nesting geese has been recorded when voles are scarce (Nolet et al. 2013); and vole population irruptions have been associated with increased fecundity of North American dabbling ducks (Ackerman 2002, Specht and Arnold 2018).

Within wet grassland landscapes, small mammals are largely restricted to patches of taller, denser vegetation swards that typically occur only in verges outside of grazed fields (Laidlaw et al. 2013), and Lapwing Vanellus vanellus nests that are closer to such verges are significantly less likely to be predated (Laidlaw et al. 2015), potentially as a result of foxes preferentially hunting small mammals (rather than wader nests) when verges are present. Modeling different scenarios of habitat management in these landscapes suggests that targeted expansion of the area of tall vegetation could potentially reduce nest predation rates by $\sim 20 \%$ (Laidlaw et al. 2017), and manipulation of tall vegetation patches is a potentially practical and feasible tool, both in intensively managed reserves and across the wider countryside. However, the effectiveness of this management approach will depend on whether foxes do indeed concentrate their activity around patches of tall vegetation in these landscapes, which types of patches might be favored, and whether patch use varies seasonally.

While small mammals are known to be confined to tall vegetation patches in wet grasslands (Laidlaw et al. 2013), the extent to which their abundance varies with the size of these patches, and thus what size patches should be the target of management actions, is unknown. Similarly, understanding whether patterns of fox activity reflect seasonal variation in small mammal activity within these patches is important because this could influence the location of managed patches in relation to the seasonal distribution of breeding birds. Consequently, here we quantify whether small mammal activity within tall vegetation patches varies with patch size and whether these patterns vary over the course of the breeding season. Then, to explore whether the resulting spatial and seasonal variation in small mammal activity is associated with fox distribution, we use fox track plots and trail cameras to quantify fox activity in relation to proximity to tall vegetation and how these patterns vary seasonally. We then use this information to consider the implications for adapting vegetation management in wet grassland landscapes to influence levels of wader nest predation.

\section{METHODS}

\section{Study sites}

Variation in small mammal activity among patches of tall vegetation (areas larger than $400 \mathrm{~m}^{2}$ ) was assessed on six wet grassland SITES (capital letters indicate model variables; Table 1 ) in east and southeast England (Strumpshaw Fen $\left[52^{\circ} 61^{\prime} \mathrm{N} 01^{\circ}\right.$ $46^{\prime} \mathrm{E}$ ], Buckenham Marshes [52 $\left.60^{\prime} \mathrm{N} 01^{\circ} 47^{\prime} \mathrm{E}\right]$, Cantley Marshes

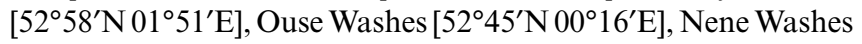

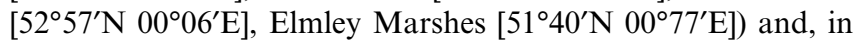

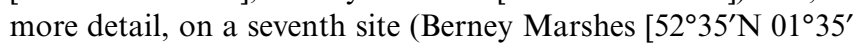
E]; Appendix 1). At the time of sampling, all of these sites were managed as nature reserves by the Royal Society for the Protection of Birds (RSPB), and management on these reserves is predominantly aimed at providing suitable habitat conditions for breeding waders, through maintenance of short swards (primarily delivered with livestock grazing) and surface wet features that contain water throughout the wader breeding season (Eglington et al. 2008, Fisher et al. 2011). Consequently, there are three distinct vegetation structures typically found within these wet grassland landscapes: short, i.e., $<10 \mathrm{~cm}$ height, vegetation within the highly managed and often wet field centers; slightly taller, $>$ $10 \mathrm{~cm}$, vegetation in the drier edges of fields, within $50 \mathrm{~m}$ of edge of field; and tall vegetation, $>20 \mathrm{~cm}$, outside fields, in verges that often follow paved roads, gravel tracks, railways, and rivers (Laidlaw et al. 2013). 
Table 1. Description of the structure of models of small mammal (SM) and fox track plot use rate and all response and explanatory variables. The maximal model is shown and was carried out in $\mathrm{R}$ (v 3.4.2).

\begin{tabular}{|c|c|c|c|}
\hline Type & Variable & $\begin{array}{l}\text { Distribution } \\
\text { (link/offset) }\end{array}$ & Definition \\
\hline \multirow[t]{2}{*}{ Response } & SM activity & Normal (identity) & Prop. of the 48 grid squares with SM prints \\
\hline & Fox track plot use rate & Binomial (logit) & $\begin{array}{l}\text { Track plot (used/not used) accounting for days track plot was active; (cbind[track plot } \\
\text { outcome, number days active]) }\end{array}$ \\
\hline \multirow{12}{*}{ Explanatory } & Site & Six sites & Six lowland wet grassland reserves in the east of England \\
\hline & Time period & Early:middle:late & Early (late March to early April); middle (May); or late (June) for nine nights each \\
\hline & Time & 10 periods & Consecutive time periods of nine nights each, from April to July \\
\hline & Location & Field:verge & Patch location, either within fields or verges outwith fields \\
\hline & Patch area & Continuous & Area $(\log 10$ transformed) of tall vegetation patches \\
\hline & Lower sward density & Continuous & Sward density in late season \\
\hline & Year & Three years & $2008-2010$ \\
\hline & Start day in season & Continuous & Day after 1 March when track plot was started \\
\hline & Distance to verge & Continuous & $\begin{array}{l}\text { Distance to field edge plus route from focal field gateway to nearest verge avoiding ditches } \\
(\mathrm{m})\end{array}$ \\
\hline & Nests within $100 \mathrm{~m}$ & Continuous & Number of active Lapwing nests hat occurred within $100 \mathrm{~m}$ of the track plot \\
\hline & Field area & Continuous & Area of field in which focal track plot located $\left(\mathrm{km}^{2}\right)$ \\
\hline & Surface water & Proportion & Proportion of focal field covered by surface water during use of track plot \\
\hline Model & Response & \multicolumn{2}{|c|}{ Model structure } \\
\hline 1 (Six sites) & SM activity & \multicolumn{2}{|c|}{ Site + Time period + Patch area + Lower sward density + (1|Patch/Tunnel $)$} \\
\hline 2 (Berney) & SM activity & \multicolumn{2}{|c|}{ Time + Location +Time*Location $+(1 \mid$ Patch/Tunnel $)$} \\
\hline 3 (Berney) & SM activity & \multicolumn{2}{|c|}{ Time + Patch area + Lower sward density + Time*Patch area (1|Patch/Tunnel) } \\
\hline 4 (Berney) & Fox track plot use rate & \multicolumn{2}{|c|}{$\begin{array}{l}\text { Start day }+ \text { Distance to verge }+ \text { Nests within } 100 \mathrm{~m}+\text { Field area }+ \text { Surface water }+ \text { Start day*Distance to verge } \\
+(1 \mid \text { Year })\end{array}$} \\
\hline
\end{tabular}

\section{Small mammal distribution and activity}

Small mammal activity was quantified using ink tracking tunnels constructed from corrugated plastic and containing an inksoaked sponge adjacent to paper treated with tannic acid on which mammal footprints are recorded, following a chemical reaction between the ink and treated paper (for details see Laidlaw et al. 2013). Two $90 \times 240 \mathrm{~mm}$ pieces of treated paper were used within each tunnel, one on each side of the sponge. The relative activity level of small mammals for each tunnel was assessed by overlaying each paper with an acetate grid (split into $30 \times 30 \mathrm{~mm}$ squares) and recording the number of squares that contained at least one whole or partial small mammal print; a maximum score of 48 was therefore possible from the two papers in each tunnel, and this metric of small mammal activity is used as a proxy for the amount of small mammal movement within the local area.

To assess the variability in small mammal activity across wet grassland sites subject to similar management criteria, ink tracking tunnels were deployed in patches of tall $(>10 \mathrm{~cm})$ vegetation on six wet grassland sites (five patches each on Strumpshaw, Buckenham, Ouse Washes, Nene Washes, and Elmley; four patches on Cantley), between April and July 2011. Within each reserve, sampled patches were spread across the site, with a mean distance between patches of $47.4 \mathrm{~m} \pm 89.6 \mathrm{SD}$. Each of the 29 patches of tall vegetation on these reserves had four ink tracking tunnels, placed a minimum of $5 \mathrm{~m}$ apart and at least 20 $\mathrm{m}$ away from gateways. Tunnels were run for a 9-night tracking period, with papers collected once at the end of this period; this was repeated in the early (April), mid (mid to late May), and late season (mid-June to early July) in 2011.

The area of each of the 29 tall vegetation patches was measured from aerial photographs in ArcGIS (ArcMap Version 9.3). Patch sward structure was measured during June and July 2011 and was measured along transects with 10 sampling locations at least $5 \mathrm{~m}$ apart, and following a zig-zag configuration to capture the variance in vegetation structure (see Laidlaw et al. 2013 for details). Sward density at ground level was measured at each sampling location as the amount of a $10 \mathrm{~cm}$ cube obscured by vegetation, estimated by eye. Sward height $(\mathrm{cm})$ was measured with a sward stick and calculated from the average of three sward height measures at each sample location (Stewart et al. 2001).

On Berney Marshes, seasonal variability in small mammal activity in patches of tall vegetation was quantified in 25 patches spread throughout the reserve, along field verges $(n=14)$ and in field edges $(n=11)$. Patch size and sward structure was measured as described above. The same tunnel sampling design was used in the 25 tall vegetation patches at Berney Marshes (Fig. 1), but the 9-night tracking periods were repeated 10 times throughout the wader breeding season, from April to late June 2011.

\section{Fox distribution and activity}

\section{Tracking plots}

To quantify the distribution of fox activity across Berney Marshes, baited track plots were deployed during each wader breeding season between 2008 and 2010 (Bodey et al. 2010, Cole 2010). Track plots were spread throughout the reserve in all years and located both at field edges and in the center of fields (Appendix 2).

Fox track plots consist of an area of $\sim 1 \mathrm{~m}^{2}$ from which turf is removed and replaced with a layer of $\sim 30-50 \mathrm{~mm}$ of smoothed sand, covered with a fine layer of topsoil (following Eglington et al. 2009). Plots centers are baited with a buried small portion $(\sim 10$ 
g) of a low-protein (5.5\%), low-oil (2\%) content dog food (brand name "Chappie"), which is a short-range bait that attracts foxes over a range of $\sim 3-5 \mathrm{~m}$ (Eglington et al. 2009). The day on which each plot was set was considered the START DAY and each plot was checked every morning for nine consecutive nights, unless rainfall was sufficiently heavy to obscure prints, in which case the track period was extended until nine dry nights had been sampled. Plots were considered to have been used when fox footprints were detected and/or when the bait had been dug up and consumed. The day on which this occurred was recorded, and these plots were then removed from the study. Eglington et al. (2009) demonstrated the very high level of accuracy in identifying foxes from footprints on track plots with the use of nest cameras trained on a subsample of track plots.

Fig. 1. The distribution of tall vegetation patches outside fields (black), and within fields (light grey) in which small mammal activity was recorded. The locations of nonsurveyed verge vegetation (dark grey) across Berney Marshes and surrounding farmed grassland are also indicated. Fields where fox (Vulpes vulpes) plots were run for at least one year between 2008 and 2010 indicated by hashed lines, see Appendix 1 for details.

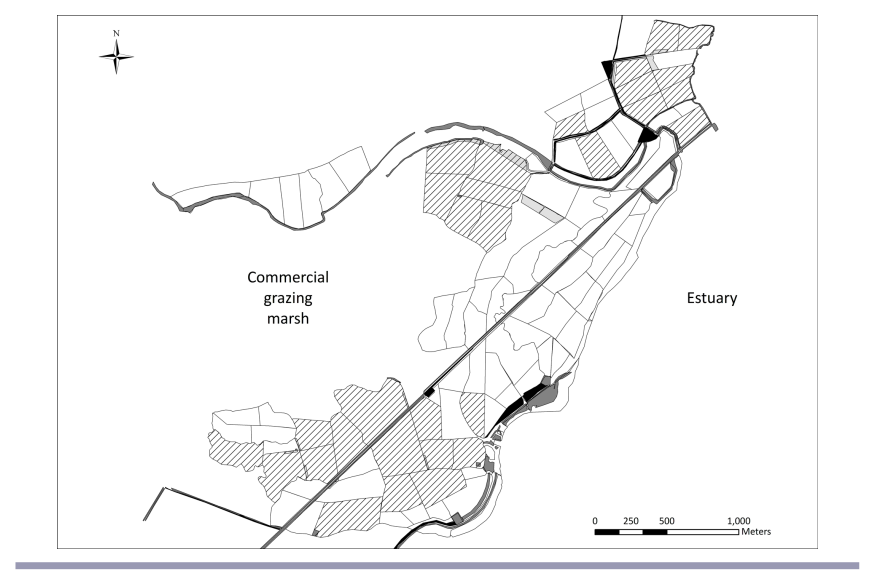

\section{Trail cameras}

To assess whether fox activity, i.e., the locations visited by foxes within this landscape, was concentrated around verges, trail cameras (RECONYX ${ }^{\mathrm{TM}}$ PC800 HyperFire ${ }^{\mathrm{TM}}$ ) were deployed at Berney Marshes to capture predator presence along 19 verges (with tall vegetation, $>20 \mathrm{~cm}$ ) and 19 field edges (with short vegetation, $>10 \mathrm{~cm}$ ), for 28 consecutive nights each during April to June 2011. Cameras were placed at a height of around $1 \mathrm{~m}$ on either existing gate posts or new posts, with cameras set to record 10 pictures per trigger, with a "rapidfire" delay between pictures and "max range" during night mode.

\section{Environmental conditions and breeding wader distribution}

The area and distribution of all patches of tall $(>10 \mathrm{~cm})$ vegetation within the Berney Marshes reserve were mapped in ArcGIS v.9.3 (Appendix 2) by digitizing outlines from aerial photographs (Millennium Map 2000, a UK-wide aerial survey displayed as a raster image at 1:2500 resolution). The network of large, deep ditches that borders fields and supplies water across the lowland wet grassland landscape, were also digitized. The DISTANCE TO VERGE for each spatially referenced track plot (Appendix 2) was calculated in ArcGIS v.10 as the sum of the minimum distance from the plot to the field edge and the distance from the nearest gateway access point of that field to the nearest tall vegetation. To calculate this distance, a cost-distance analysis was used (following Laidlaw et al. 2017) in which routes that crossed ditches were excluded by assigning them prohibitively high values of resistance to movement, while all other land-types were assigned no resistance to movement. Ditches that surround these fields are likely to act as barriers to the movement of groundpredators, and predators are therefore most likely to access fields through the dry access provided by gateways. FIELD SIZE was also measured in ArcGIS v.10 for each focal field.

Around each track plot, a $100 \mathrm{~m}$ radius buffer was drawn in ArcGIS v.10, and all active, i.e., in the incubation stage at any point during the nine-day track plot monitoring period, Lapwing NESTS WITHIN $100 \mathrm{M}$ were counted. This measure of Lapwing density was included in the analyses to determine whether the local activity of breeding waders and, in particular, defensive behavior of nesting Lapwing, may be influencing fox movement. In all years plots were run in the early season (mostly in April, to correspond with the first wader nesting attempts), and again in the late season (between mid-May and late June, to correspond with later nests and chick rearing; Appendix 2).

\section{Annual and seasonal variation in extent of surface water}

Using GPS locations of all footdrains (shallow channels of varying width designed to hold water within fields), the extent of SURFACE WATER within each field was estimated. High water levels, which result in pools forming around overtopped footdrains, are maintained on the reserve over winter, and the maximum extent of surface water in fields was mapped in March of two years (2009 and 2011). From these maps, a five-category surface flooding score that reflected the range of surface flooding across the reserve was developed (maximum extent, $\sim 75 \%, \sim 50 \%, \sim 25 \%$ extent and water in footdrains only) and mapped in ArcGIS v.10. Surface flooding categories were assigned to each focal field over the season to capture seasonal reductions in surface flooding following Laidlaw et al. (2017).

\section{Statistical analyses}

General linear mixed models were used to determine the influence on small mammal activity (proportion of tracking paper with prints in each tunnel) of (a) patch size and sward density across six reserves (Table 1: Model 1), (b) patch location at Berney Marshes (Table 1: Model 2), and (c) patch size, interaction of patch size and time and sward density at Berney Marshes (Table 1: Model 3). Because of strong collinearity between sward height and density at Berney Marshes in both the early (March and April: $\mathrm{r}=0.90, \mathrm{n}=1000, \mathrm{p}<0.001)$ and late (June: $\mathrm{r}=0.76, \mathrm{n}=1000$, $\mathrm{p}<0.001)$ season, only late season sward density was used in all analyses of sward characteristics, as this variable was considered likely to have the greatest biological relevance for small mammals. To account for nonindependence of the four tunnels deployed in each sampling location, Models 1-3 (Table 1) include a random factor of tunnel identity nested within sampled habitat patch. 
Table 2. Results of generalized linear mixed models exploring the influence on small mammal activity of Model 1: patch area and sward density at all reserves (controlling for site and seasonal [time period] variation), Model 2: patch location at Berney Marshes (controlling for seasonal variation); and Model 3: patch area and sward density at Berney Marshes (controlling for seasonal variation). Both maximum models and minimal models with $\mathrm{R}^{2}$ are shown. Results in bold are statistically significant.

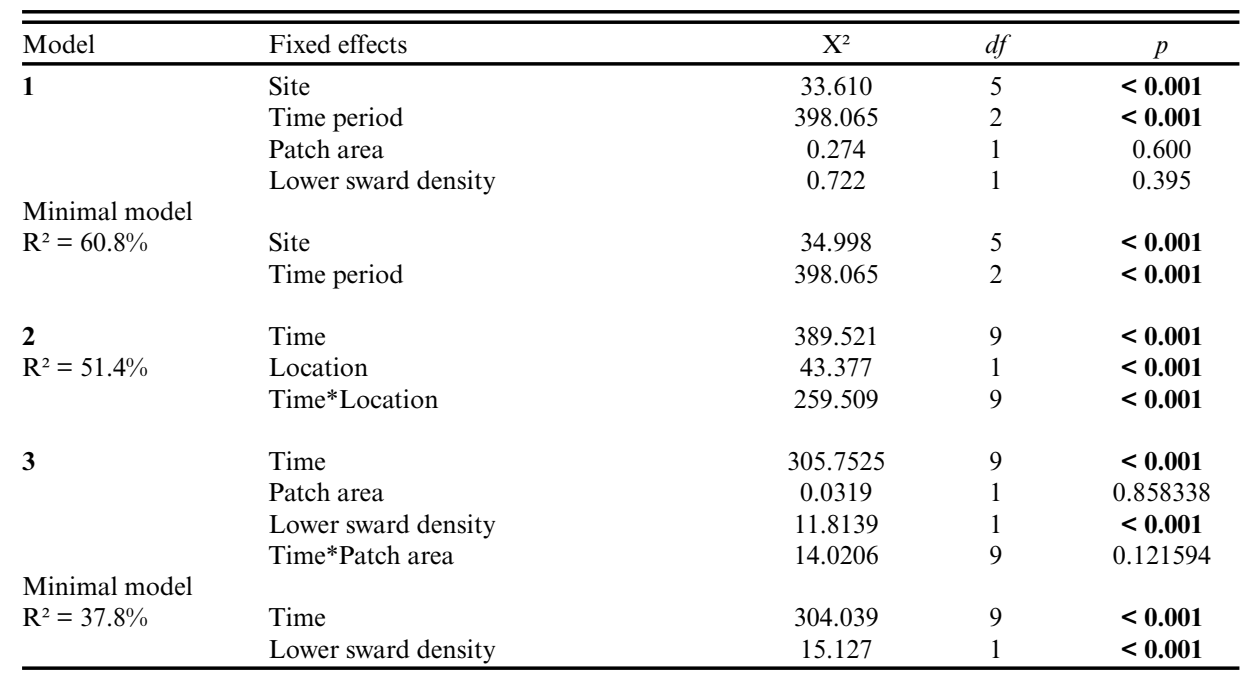

The daily use rate (DUR) of the track plots (over the nine night observation period) was modeled using a formulation of Mayfield's (1961, 1975) method as a logistic model with a binomial error term, in which success (not used by fox) or failure (used by fox) was modeled with the number of exposure days as the binomial denominator (Aebischer 1999). Details of the track plots model variables and interactions are in Table 1 (Model 4). Daily use rates predicted from these models were then transformed to probabilities of not being used by a fox (S) by raising the daily nonuse rate (1-DUR) to the power of the number of nights the track plots were run (nine). The probability of track plot use over the track period was then calculated as 1-S.

Nonsignificant $(p>0.05)$ interactions were removed by backward deletion from full models. We used GLMM with function glmer in $\mathrm{R}$ 3.4.2 ( $\mathrm{R}$ Core Team 2017).

The number of nights on which foxes were recorded on trail cameras in verges was compared to those recorded within fields using a Fisher's exact test R (v 3.4.2). The small sample size of cameras recording fox activity (4/38) prohibited a meaningful analysis of the frequency of verge and field use by foxes.

\section{RESULTS}

\section{Variation in small mammal activity on wet grasslands}

Across six wet grassland reserves in eastern England, small mammal activity increased significantly over the course of the season, with activity levels being more than three times higher in June than in April in all sites (Table 2 Model 1, Fig. 2a). However, despite patch sizes in the six sites ranging from $\sim 0.0004$ to 0.05 $\mathrm{km}^{2}$, small mammal activity did not vary significantly with patch area or sward density (Figs. $2 \mathrm{~b}$ and c).
Small mammal activity also increased significantly over the course of the wader breeding season at Berney, but only in the patches of tall vegetation that were in field verges, and not in field edges, where vegetation was typically less dense (Table 2 Model 2, Fig. 2d). Small mammal activity also did not vary with patch size at this site and this was also not influenced by the time in the season (Table 2 Model 3, Fig. 2e). However, patches with a denser sward had significantly more small mammal activity, with the denser swards of verges ( $>90 \%$ cover) having roughly three times the small mammal activity of the least dense swards, which were all in field edges $(<10 \%$ cover; Table 2 Model 3, Fig. 2f). Small mammal activity in wet grasslands is therefore concentrated in field verges with dense vegetation, particularly later in the season when activity levels are greatest.

\section{Variation in fox activity on wet grasslands}

Between 32 and $48 \%$ of track plots were visited by foxes in each year of the study, except for 2010 , when nearly $95 \%$ of the track plots were visited (Fig. 3a). Between 40 and $60 \%$ of the track plots were visited by foxes regardless of distance to verge (Fig. 3c). Relatively few track plots were situated in areas of high Lapwing density because these are now rare in this landscape (Fig. 3d). There was a seasonal decline in the likelihood of track plots being used by foxes (Table 3, Fig. 3a), from $\sim 60 \%$ (April) to $30 \%$ (June). Use of track plots did not vary with distance to verge, nor was there any seasonal effect of distance to verge on track plot use, i.e., no significant interaction between season and distance to verge (Table 3). Similarly, track plot use did not vary with the extent of surface water in the surrounding field (Table 3 ). However, of the 325 track plots included in the analysis, 169 had no active Lapwing nests recorded within $100 \mathrm{~m}$ (Fig. 3d), and plots were significantly more likely to be used by foxes when there were fewer active Lapwing nests within $100 \mathrm{~m}$ (Table 3, Fig. 4b). Track plots with many $(\sim 7)$ surrounding Lapwing nests were $\sim 20 \%$ less likely to be used than plots with no nearby active nests (Fig. 4b). 
Table 3. Results of generalised linear mixed model (with binomial errors) of Model 4: track plot survival over a nine-night period. Both the maximum model and the minimal model $\left(\mathrm{R}^{2}=\right.$ $19 \%$ ) are shown. Estimates and SE are logits. Results in bold are statistically significant.

\begin{tabular}{|c|c|c|c|c|}
\hline Variable & Estimate & Std. Error & $\mathrm{z}$ value & $\operatorname{Pr}(>|z|)$ \\
\hline (Intercept) & -2.511 & 0.489 & -5.131 & $<0.001$ \\
\hline Start day & -0.274 & 0.104 & -2.626 & 0.009 \\
\hline Distance to verge & -0.160 & 0.101 & -1.584 & 0.113 \\
\hline Nests within $100 \mathrm{~m}$ & -0.254 & 0.087 & -2.923 & 0.003 \\
\hline Field area & -0.086 & 0.084 & -1.020 & 0.308 \\
\hline Surface water & 0.081 & 0.101 & 0.803 & 0.422 \\
\hline Start day $*$ Distance to verge & -0.108 & 0.091 & -1.191 & 0.234 \\
\hline \multicolumn{5}{|l|}{ Minimal model } \\
\hline (Intercept) & -2.493 & 0.475 & -5.249 & $<0.001$ \\
\hline Start day & -0.328 & 0.091 & -3.608 & $<0.001$ \\
\hline Nests within $100 \mathrm{~m}$ & -0.258 & 0.082 & -3.130 & 0.002 \\
\hline
\end{tabular}

Fig. 2. Small mammal activity (percentage cover of tracking papers with small mammal prints): (a) on six wet grassland nature reserves (mean $\pm \mathrm{SE}$ ) during early (open bars), mid (light grey bars) and late season (dark grey bars) and, on tall vegetation patches across these six reserves (Buckenham: open circle, Cantley: closed circle, Strumpshaw: open square, Ouse Washes: closed square, Nene Washes: open triangle, and Elmley Marshes: closed triangle) that vary in (b) area and (c) groundlevel sward density (Table 2 Model 1). (d) Seasonal variation in small mammal activity in tall vegetation patches in verges (closed bars) and field edges (open bars) at Berney Marshes, between 27 March and 25 June 2011 (Table 2 Model 2), and small mammal activity across 25 tall vegetation patches varying in (e) area, (f) ground-level sward density, and located either in verges (closed) or within fields (open) at Berney Marshes (Table 2 Model 3).
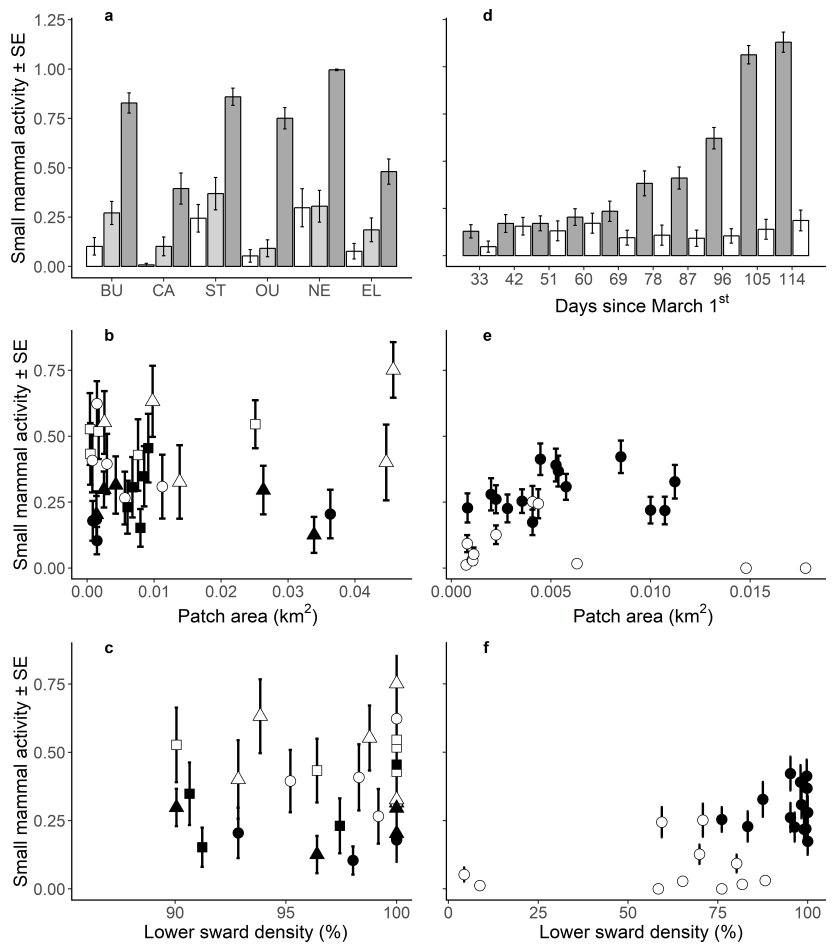

Fig. 3. Numbers of track plots that were (open bars) or were not (grey bars) visited by foxes in relation to (a) year, (b) days since 1 March, (c) distance to verge, (d) number of active Lapwing (Vanellus vanellus) nests within $100 \mathrm{~m}$, (e) field area, and (f) proportion of field flooded.
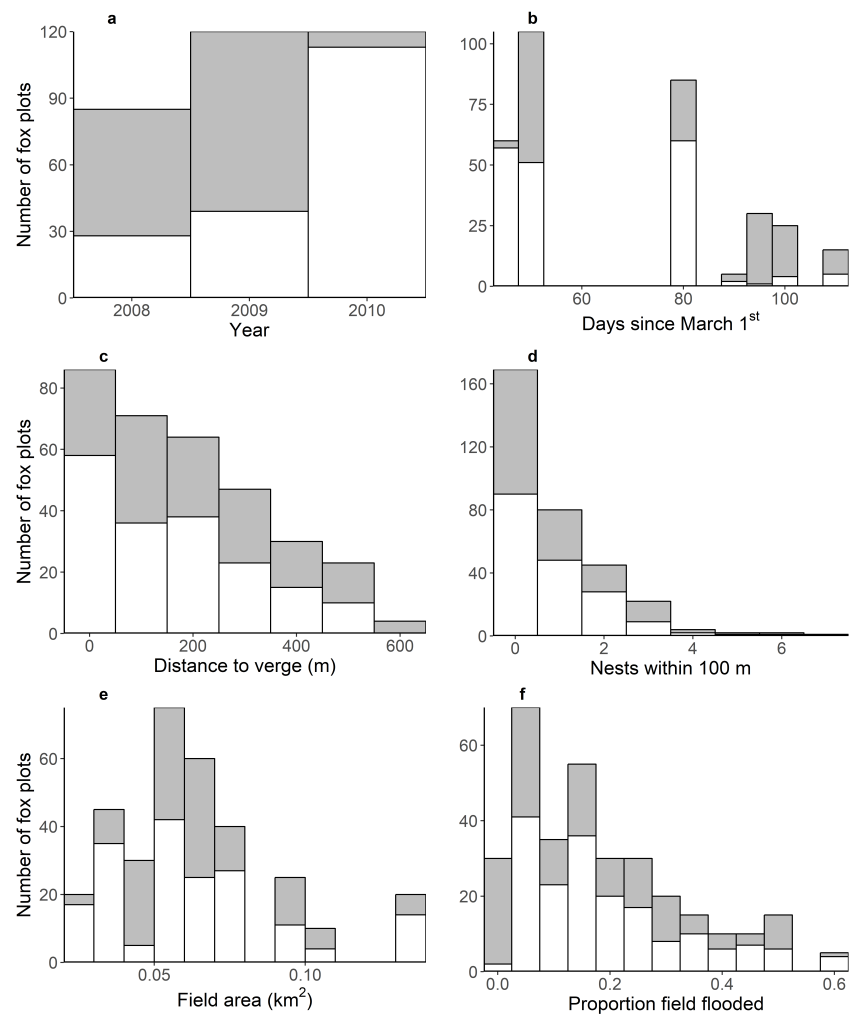

Of the 19 trail cameras located along verges with tall vegetation and 19 along field edges with short vegetation, fox images were captured at two verge and two field edge locations. However, the trail cameras that were located along verges recorded significantly more fox activity (although number of individual foxes was not known), with foxes being recorded on 13 separate nights (of the 1064 camera-nights), while both within-field cameras only 
captured foxes on a single night each (Fisher's exact test, $\mathrm{p}=$ 0.038). Thus, fox activity was more commonly recorded next to tall vegetation than in areas of short vegetation but very few foxes were recorded overall, and so these findings should be treated with caution.

Fig. 4. Changes in the predicted probability of fox (Vulpes vulpes) use of track plots ( $\pm 95 \% \mathrm{CI}$ ) over nine-night study periods with increasing (a) time since 1 March and (b) number of active Lapwing (Vanellus vanellus) nests within $100 \mathrm{~m}$. Predictions used are from models in Table 3.

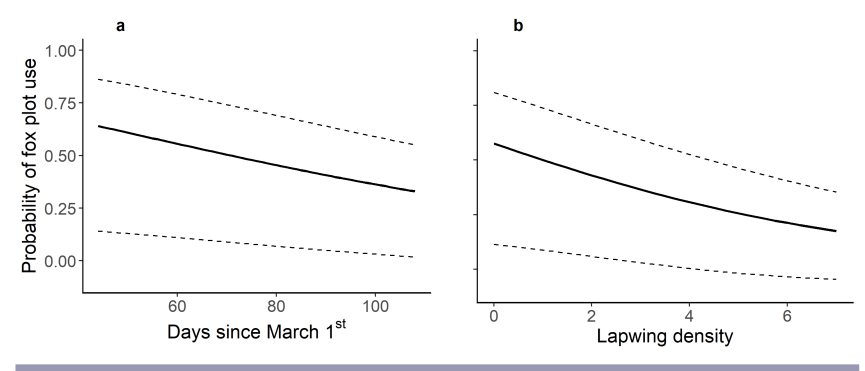

\section{DISCUSSION}

Across wet grassland reserves that are managed primarily for breeding waders, small mammal activity increased significantly through the breeding season, but did not vary with patch size ( $>$ $0.05 \mathrm{ha}$, the minimum recorded in the study), but activity levels were greater in patches with dense ground-level sward structure. The activity measure used in this study (frequency of prints within tracking tunnels) is a relative, rather than absolute, measure of activity and may not reflect variation in abundance. The consistently high late-season small mammal activity (tracking papers with $\sim 80 \%$ print coverage), across all seven sites suggests, however, that similar seasonal changes in small mammal activity and patch structure are likely to operate across wet grasslands. Seasonal increases in small mammal activity are likely to reflect juvenile dispersal, which may increase use of lower quality habitats (e.g. Collins and Barrett 1997). The seasonal increase in small mammal activity in tall vegetation patches was mirrored by a decrease in fox use of track plots within fields. This suggests that fox distribution and activity in these wet grassland landscapes could be influenced by the distribution of small mammals and the vegetation patches in which they occur.

Previous work in this landscape has shown that predation of Lapwing nests is lower near the tall vegetation of verges, with nests adjacent to verges having a $\sim 60 \%$ predation probability compared to a $\sim 90 \%$ predation probability for nests $\sim 1 \mathrm{~km}$ from verges (Laidlaw et al. 2015, 2017). Verge vegetation structure is typically taller and denser than within-field vegetation because of a lack of grazing and water management. The presence of small mammals in verges, combined with the cover provided by this tall vegetation in an otherwise open landscape, could lead to fox activity being concentrated around these areas. Trail cameras placed next to tall vegetation recorded significantly more fox activity than cameras in areas with short vegetation, but foxes were recorded on only four cameras overall, and thus more evidence is needed to confirm this concentration of fox activity around tall vegetation.
Although trail cameras suggested a possible concentration of fox activity close to tall vegetation, fox use of track plots did not vary with proximity to tall vegetation. This latter finding is consistent with previous studies that found no evidence of fox use of track plots being concentrated around field edges or close to linear features (Eglington et al. 2009). The contrast between track plots and cameras suggests that foxes do not avoid areas that are distant from tall vegetation, i.e., they occur throughout the landscape, in areas with and without tall vegetation. However, the concentration of trail camera records of foxes next to tall vegetation, and the lower predation rate of Lapwing nests close to these areas (Laidlaw et al. 2015, 2017) suggests that foxes may stay close to tall vegetation when it is present. The seasonal decline in track plot use mirrors the seasonal increase in small mammal activity in field verges, and could thus reflect foxes increasingly concentrating their activity around field verges as the season progresses. Because the density of the ground-level sward is particularly important for small mammals (Tattersall et al. 2000), the denser swards outside fields may provide the best substrate for small mammal runs to be constructed in vegetation with sufficient cover from predators. Over the course of the season, the vegetation within these habitats is also continually growing (Laidlaw et al. 2013) which, in combination with increasing small mammal abundance, could be making these habitats increasingly attractive to foxes as the season progresses. Wader nest and chick availability increases through April and May before declining rapidly in June (Eglington et al. 2008). Foxes may therefore be concentrating activity within fields when wader nests are abundant and small mammals are scarce, but switching to field verges when small mammal abundance increases and the number of wader nests declines. This would suggest that the presence of verges might be more likely to influence fox predation of late nests and chicks than of early nests. Verges may also provide perches and small mammal prey for avian predators, which can also be important predators of wader chicks (Mason et al. 2018).

Fox use of track plots was significantly less likely in areas with higher densities of nesting Lapwing, which is consistent with previous studies showing that nest predation rates decline with increasing Lapwing nesting densities (Eglington et al. 2009, Laidlaw et al. 2017). Lapwings have been shown to direct their mobbing defence behavior at foxes during nocturnal observations (Seymour et al. 2003), and predator mobbing can be an effective form of nest defence (Elliot 1985). Foxes encountering Lapwing mobbing, particularly by multiple individuals, may change their direction or speed of movement so that they are less likely to encounter a fox tracking plot. Focusing habitat management in areas that can support high densities of nesting Lapwing may therefore be among the most effective of measures to reduce predator impacts.

\section{Implications for wet grassland management}

In wet grassland landscapes managed for breeding waders, small mammals are primarily found in the tall, dense vegetation in verges and rarely within fields. Our findings suggest that structure (especially ground-level sward density) of tall habitat patches is more important than patch size in determining small mammal distribution within these environments. Verges support the great majority of the main small mammal prey of mammalian and avian predators in wet grasslands. The management of verge 
structure and location is therefore key to encouraging small mammal populations in wet grasslands. As predation of wader nests is reduced in areas close to patches supporting small mammals (Laidlaw et al. 2015), encouraging small mammals through appropriate habitat creation may serve to both boost small mammal populations and reduce the unsustainably high levels of wader nest predation that occur across Europe at present (MacDonald and Bolton 2008).

Establishing and encouraging dense verge vegetation in wet grassland landscapes could therefore potentially increase the prey available for generalist predators. Verge creation could be a flexible management tool because relatively small areas of verge can provide suitable conditions for small mammals. The tall vegetation patches in this study were selected as being representative of those currently available in the landscape, and were predominantly narrow verges that bordered tracks, paths, or rail and river embankments. There is, however, scope for altering verge configuration, for example through the addition or maintenance of tall grasses and reeds along ditches. Tall vegetation could also be developed within fields that are either not appropriate for breeding waders, e.g., very dry fields (Eglington et al. 2008), or likely to be poorer quality, e.g., fields that lack foraging areas for chicks (Eglington et al. 2010), by reducing levels of grazing and cutting.

The findings of this study also suggest that there may be potential to concentrate management to attract waders into areas that can support nesting densities that are high enough to provide protective benefits of antipredator mobbing. Future work that aimed to track foxes using GPS collar technology could be used to determine fine-scale predator use of wet grassland landscapes, and therefore usefully inform future habitat manipulations aimed at altering their behavior, ultimately to reduce predation on breeding waders.

Experimental manipulations of habitat management to create tall vegetation patches at differing distances from breeding wader fields would allow the interaction between small mammal distribution, predator activity, and wader nest predation to be assessed. The design and creation of tall habitat patches for small mammals within lowland wet grassland landscapes could then potentially become an important management tool to reduce levels of predation of breeding waders and to encourage greater species and habitat diversity within grassland landscapes.

Responses to this article can be read online at: http://www.ace-eco.org/issues/responses.php/1414

\section{Acknowledgments:}

This project was funded by UEA, the John and Pamela Salter Charitable Trust, the RSPB, and NERC (grant no. NE/ P002986/1). We thank all the landowners for access to their grazing marshes, and RSPB staff and students for their assistance in the field.

\section{LITERATURE CITED}

Ackerman, J. T. 2002. Of mice and mallards: positive indirect effects of coexisting prey on waterfowl nest success. Oikos 99 (3):469-480. https://doi.org/10.1034/j.1600-0706.2002.11802.x

Aebischer, N. J. 1999. Multi-way comparisons and generalized linear models of nest success: extensions of the Mayfield method. Bird Study 46:S22-S31. https://doi.org/10.1080/00063659909477228

Aharon-Rotman, Y., M. Soloviev, C. Minton, P. Tomkovich, C. Hassell, and M. Klaassen. 2015. Loss of periodicity in breeding success of waders links to changes in lemming cycles in Arctic ecosystems. Oikos 124:861-870. https://doi.org/10.1111/oik.01730

Alterio, N., H. Moller, and H. Ratz. 1998. Movements and habitat use of feral house cats Felis catus, stoats Mustela erminea and ferrets Mustela furo, in grassland surrounding Yellow-eyed Penguin Megadyptes antipodes breeding areas in spring. Biological Conservation 83:187-194. https://doi.org/10.1016/ S0006-3207(97)00052-9

Ausden, M., and G. J. M. Hirons. 2002. Grassland nature reserves for breeding wading birds in England and the implications for the ESA agri-environment scheme. Biological Conservation 106:279-291. https://doi.org/10.1016/S0006-3207(01)00254-3

Bodey, T. W., J. Smart, M. A. Smart, and R. D. Gregory. 2010. Reducing the impacts of predation on ground-nesting waders: a new landscape-scale solution? Aspects of Applied Biology 100:167-174.

Bolton, M., G. Tyler, K. Smith, and R. Bamford. 2007. The impact of predator control on Lapwing Vanellus vanellus breeding success on wet grassland nature reserves. Journal of Applied Ecology 44:534-544. https://doi.org/10.1111/j.1365-2664.2007.01288.x

Carter, S., and P. Bright. 2002. Habitat refuges as alternatives to predator control for the conservation of endangered Mauritian birds. Pages 71-78 in C. R. Veitch and M. N. Clout, editors. Turning the tide: the eradication of invasive species. Proceedings of the International Conference on Eradication of Island Invasives. International Union for Conservation of Nature, Gland, Switzerland.

Cole, T. 2010. Reducing the impacts of predation on ground-nesting waders: a new landscape-scale solution? Thesis. Wildlife Management Conservation, University of Reading, Reading, UK.

Collins, R. J., and G. W. Barrett. 1997. Effects of habitat fragmentation on meadow vole (Microtus pennsylvanicus) population dynamics in experiment landscape patches. Landscape Ecology 12:63-76. https://doi.org/10.1007/BF02698208

Colman, N. J., C. E. Gordon, M. S. Crowther, and M. Letnic. 2014. Lethal control of an apex predator has unintended cascading effects on forest mammal assemblages. Proceedings of the Royal Society of London B Biological Sciences 281:20133094. https://doi.org/10.1098/rspb.2013.3094

Dell'Arte, G. L., T. Laaksonen, K. Norrdahl, and E. Korpimäki. 2007. Variation in the diet composition of a generalist predator, the red fox, in relation to season and density of main prey. Acta Oecologica 31(3):276-281. https://doi.org/10.1016/j.actao.2006.12.007 
Avian Conservation and Ecology 14(2): 4

http://www.ace-eco.org/vol14/iss2/art4/

Eglington, S. M., M. Bolton, M. A. Smart, W. J. Sutherland, A. R. Watkinson, and J. A. Gill. 2010. Managing water levels on wet grasslands to improve foraging conditions for breeding Northern Lapwing Vanellus vanellus. Journal of Applied Ecology 47:451-458. https://doi.org/10.1111/j.1365-2664.2010.01783.x

Eglington, S. M., J. A. Gill, M. Bolton, M. A. Smart, W. J. Sutherland, and A. R. Watkinson. 2008. Restoration of wet features for breeding waders on lowland grassland. Journal of Applied Ecology 45:305-314. https://doi.org/10.1111/

j.1365-2664.2007.01405.x

Eglington, S. M., J. A. Gill, M. A. Smart, W. J. Sutherland, A. R. Watkinson, and M. Bolton. 2009. Habitat management and patterns of predation of Northern Lapwings on wet grasslands: the influence of linear habitat structures at different spatial scales. Biological Conservation 142:314-324. https://doi.org/10.1016/j. biocon.2008.10.027

Elliot, R. D. 1985. The exclusion of avian predators from aggregations of nesting Lapwings (Vanellus vanellus). Animal Behaviour 33:308-314. https://doi.org/10.1016/S0003-3472(85) 80144-5

Evans, K. L. 2004. The potential for interactions between predation and habitat change to cause population declines of farmland birds. Ibis 146:1-13. https://doi.org/10.1111/

j.1474-919X.2004.00231.x

Fisher, B., R. B. Bradbury, J. E. Andrews, M. Ausden, S. BenthamGreen, S. M. White, and J. A. Gill. 2011. Impacts of species-led conservation on ecosystem services of wetlands: understanding co-benefits and tradeoffs. Biodiversity and Conservation 20:2461-2481. https://doi.org/10.1007/s10531-011-9998-y

Forman, D. W. 2005. An assessment of the local impact of native predators on an established population of British water voles (Arvicola terrestris). Journal of Zoology 266(3):221-226. https:// doi.org/10.1017/S0952836905006795

Gibbons, D. W., A. Amar, G. Q. A. Anderson, M. Bolton, R. B. Bradbury, M. A. Eaton, A. D. Evans, M. C. Grant, R. D. Gregory, G. M. Hilton, G. J. M. Hirons, J. Hughes, I. Johnstone, P. Newbery, W. J. Peach, N. Ratcliffe, K. W. Smith, R. W. Summers, P. Walton, and J. D. Wilson. 2007. The predation of wild birds in the UK: a review of its conservation impact and management. Research Report no 23, Royal Society for the Protection of Birds, Sandy, UK.

Gorini, L., J. D. C. Linnell, R. May, M. Panzacchi, L. Boitani, M. Odden, and E. B. Nilsen. 2012. Habitat heterogeneity and mammalian predator-prey interactions. Mammal Review 42:55-77. https://doi.org/10.1111/j.1365-2907.2011.00189.x

Hayhow, D. B., M. A. Ausden, R. B. Bradbury, D. Burnell, A. I. Copeland, H. Q. P. Crick, M. A. Eaton, T. Frost, P. V. Grice, C. Hall, and S. J. Harris. 2017. The state of the UK's birds 2017. RSPB, BTO, WWT, DAERA, JNCC, NE and NRW, Sandy, UK.

Laidlaw, R. A., J. Smart, M. A. Smart, and J. A. Gill. 2013. Managing a food web: impacts on small mammals of managing grasslands for breeding waders. Animal Conservation 16:207-215. https://doi.org/10.1111/j.1469-1795.2012.00586.x

Laidlaw, R. A., J. Smart, M. A. Smart, and J. A. Gill. 2015. Influence of landscape features on nest predation rates of grassland-breeding waders. Ibis 157:700-712. https://doi. org/10.1111/ibi.12293

Laidlaw, R. A., J. Smart, M. A. Smart, and J. A. Gill. 2017. Scenarios of habitat management options to reduce predator impacts on nesting waders. Journal of Applied Ecology 54:1219-1229. https://doi.org/10.1111/1365-2664.12838

MacDonald, M. A., and M. Bolton. 2008. Predation on wader nests in Europe. Ibis 150:54-73. https://doi.org/10.1111/ j.1474-919X.2008.00869.X

Malpas, L. R., R. J. Kennerley, G. J. M. Hirons, R. D. Sheldon, M. Ausden, J. C. Gilbert, and J. Smart. 2013. The use of predatorexclusion fencing as a management tool improves the breeding success of waders on lowland wet grassland. Journal for Nature Conservation 21:37-47. https://doi.org/10.1016/j.jnc.2012.09.002

Marshall, K. N., A. C. Stier, J. F. Samhouri, R. P. Kelly, and E. J. Ward. 2016. Conservation challenges of predator recovery. Conservation Letters 9:70-78. https://doi.org/10.1111/conl.12186

Mason, L. R., J. Smart, and A. L. Drewitt. 2018. Tracking day and night provides insights into the relative importance of different wader chick predators. Ibis 160:71-88. https://doi. org/10.1111/ibi.12523

Mayfield, H. F. 1961. Nesting success calculated from exposure. Wilson Bulletin 73:255-261.

Mayfield, H. F. 1975. Suggestions for calculating nest success. Wilson Bulletin 87:456-466.

Nolet, B. A., S. Bauer, N. Feige, Y. I. Kokorev, I. Y. Popov, and B. S. Ebbinge. 2013. Faltering lemming cycles reduce productivity and population size of a migratory Arctic goose species. Journal of Animal Ecology 82(4):804-813. https://doi.org/10.1111/1365-2656.12060

O'Brien, M., and J. D. Wilson. 2011. Population changes of breeding waders on farmland in relation to agri-environment management. Bird Study 58:399-408. https://doi. org/10.1080/00063657.2011.608117

R Core Team. 2017. R: A language and environment for statistical computing. R Foundation for Statistical Computing, Vienna, Austria.

Rickenbach, O., M. U. Grüebler, M. Schaub, A. Koller, B. NaefDaenzer, and L. Schifferli. 2011. Exclusion of ground predators improves Northern Lapwing Vanellus vanellus chick survival. Ibis 153:531-542. https://doi.org/10.1111/j.1474-919X.2011.01136.X

Ritchie, E. G., and C. N. Johnson. 2009. Predator interactions, mesopredator release and biodiversity conservation. Ecology Letters 12:982-998. https://doi.org/10.1111/j.1461-0248.2009.01347. $\mathrm{x}$

Roos, S., J. Smart, D. W. Gibbons, and J. D. Wilson. 2018. A review of predation as a limiting factor for bird populations in mesopredator-rich landscapes: a case study of the UK. Biological Reviews 93:1915-1937. https://doi.org/10.1111/brv.12426

Seymour, A. S., S. Harris, C. Ralston, and P. C. L. White. 2003. Factors influencing the nesting success of Lapwings Vanellus vanellus and behaviour of Red Fox Vulpes vulpes in Lapwing nesting sites. Bird Study 50:39-46. https://doi.org/10.1080/00063650309461288 
Smart, J., A. Amar, M. O'Brien, P. Grice, and K. Smith. 2008. Changing land management of lowland wet grasslands of the UK: impacts on snipe abundance and habitat quality. Animal Conservation 11:339-351. https://doi.org/10.1111/j.1469-1795.2008.00189. $\mathrm{x}$

Smart, J., J. A. Gill, W. J. Sutherland, and A. R. Watkinson. 2006. Grassland-breeding waders: identifying key habitat requirements for management. Journal of Applied Ecology 43:454-463. https:// doi.org/10.1111/j.1365-2664.2006.01166.x

Smith, R. K., A. S. Pullin, G. B. Stewart, and W. J. Sutherland. 2010. Effectiveness of predator removal for enhancing bird populations. Conservation Biology 24:820-829. https://doi. org/10.1111/j.1523-1739.2009.01421.X

Specht, H. M., and T. W. Arnold. 2018. Banding age ratios reveal prairie waterfowl fecundity is affected by climate, density dependence and predator-prey dynamics. Journal of Applied Ecology 55(6):2854-2864. https://doi.org/10.1111/1365-2664.13186

Stewart, K. E. J., N. A. D. Bourn, and J. A. Thomas. 2001. An evaluation of three quick methods commonly used to assess sward height in ecology. Journal of Applied Ecology 38:1148-1154. https://doi.org/10.1046/j.1365-2664.2001.00658.x

Summers, R. W., and L. G. Underhill. 1987. Factors related to breeding production of Brent Geese Branta b. bernicla and waders (Charadrii) on the Taimyr Peninsula. Bird Study 34(2):161-171. https://doi.org/10.1080/00063658709476955

Tattersall, F. H., A. E. Avundo, W. J. Manley, B. J. Hart, and D. W. Macdonald. 2000. Managing set-aside for field voles (Microtus agrestis). Biological Conservation 96(1):123-128. https://doi. org/10.1016/S0006-3207(99)00098-1

Thirgood, S. J., S. M. Redpath, D. T. Haydon, P. Rothery, I. Newton, and P. J. Hudson. 2000. Habitat loss and raptor predation: disentangling long- and short-term causes of Red Grouse declines. Proceedings of the Royal Society of London B Biological Sciences 267:651-656. https://doi.org/10.1098/rspb.2000.1051

Wilson, A. M., M. Ausden, and T. P. Milsom. 2004. Changes in breeding wader populations on lowland wet grasslands in England and Wales: causes and potential solutions. Ibis 146:32-40. https://doi.org/10.1111/j.1474-919X.2004.00371.x

Wilson, A., J. Vickery, and C. Pendlebury. 2007. Agri-environment schemes as a tool for reversing declining populations of grassland waders: mixed benefits from environmentally sensitive areas in England. Biological Conservation 136:128-135. https://doi. org/10.1016/j.biocon.2006.11.010

Woodroffe, R., and S. M. Redpath. 2015. When the hunter becomes the hunted. Science 348:1312-1314. https://doi. org/10.1126/science.aaa8465 
Appendix 1. Locations of the seven RSPB-managed (at time of sampling) wet grassland nature reserves in the east of England (inset) used in the study, including the main study site at Berney Marshes.

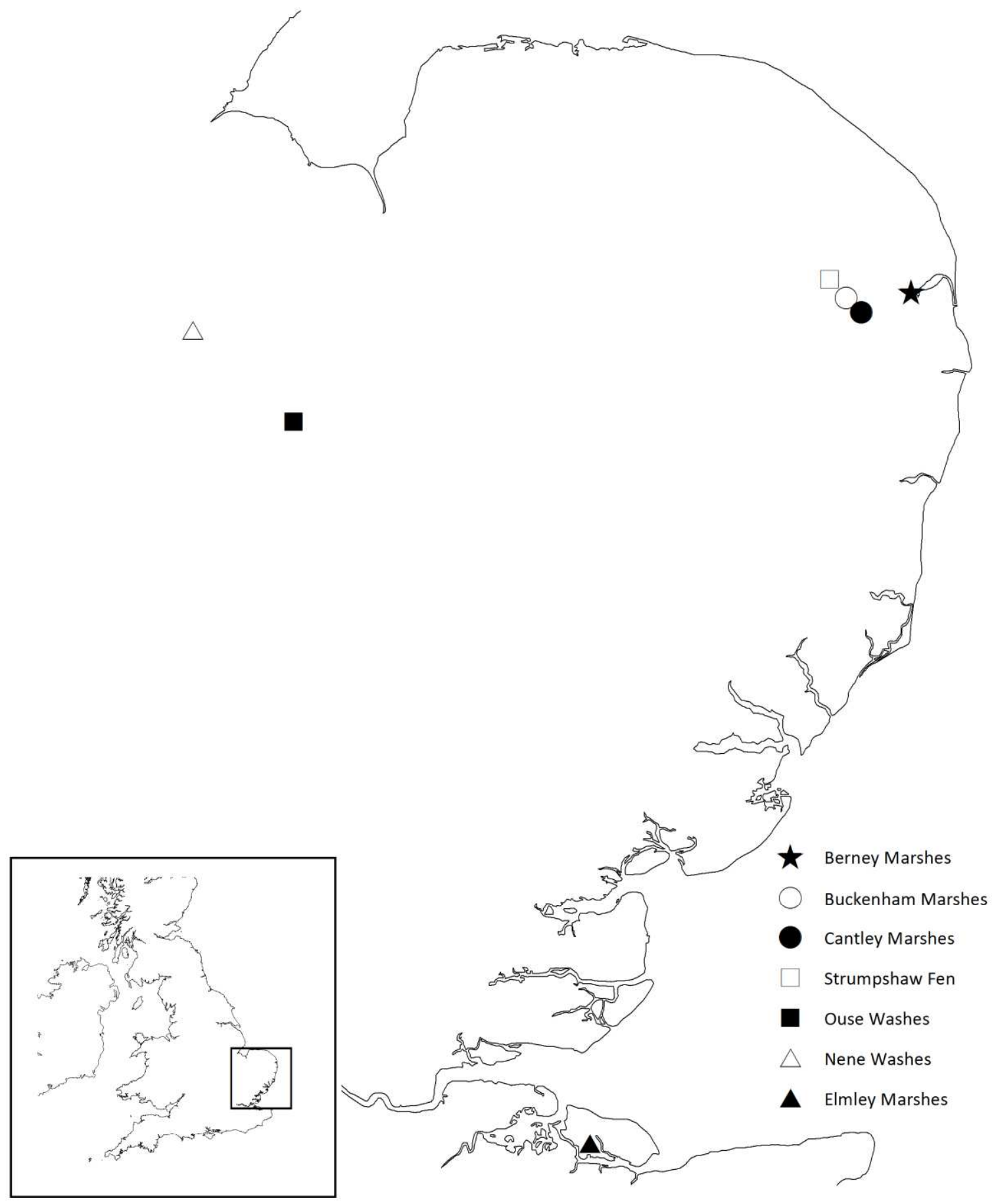


Appendix 2. The distribution of track plots that were (•) and were not ( $\left.{ }^{\circ}\right)$ visited by foxes in relation to the month of deployment between 2008 and 2010 at Berney Marshes. Fields in 2010 were sampled twice, all other fields sampled in only one month.

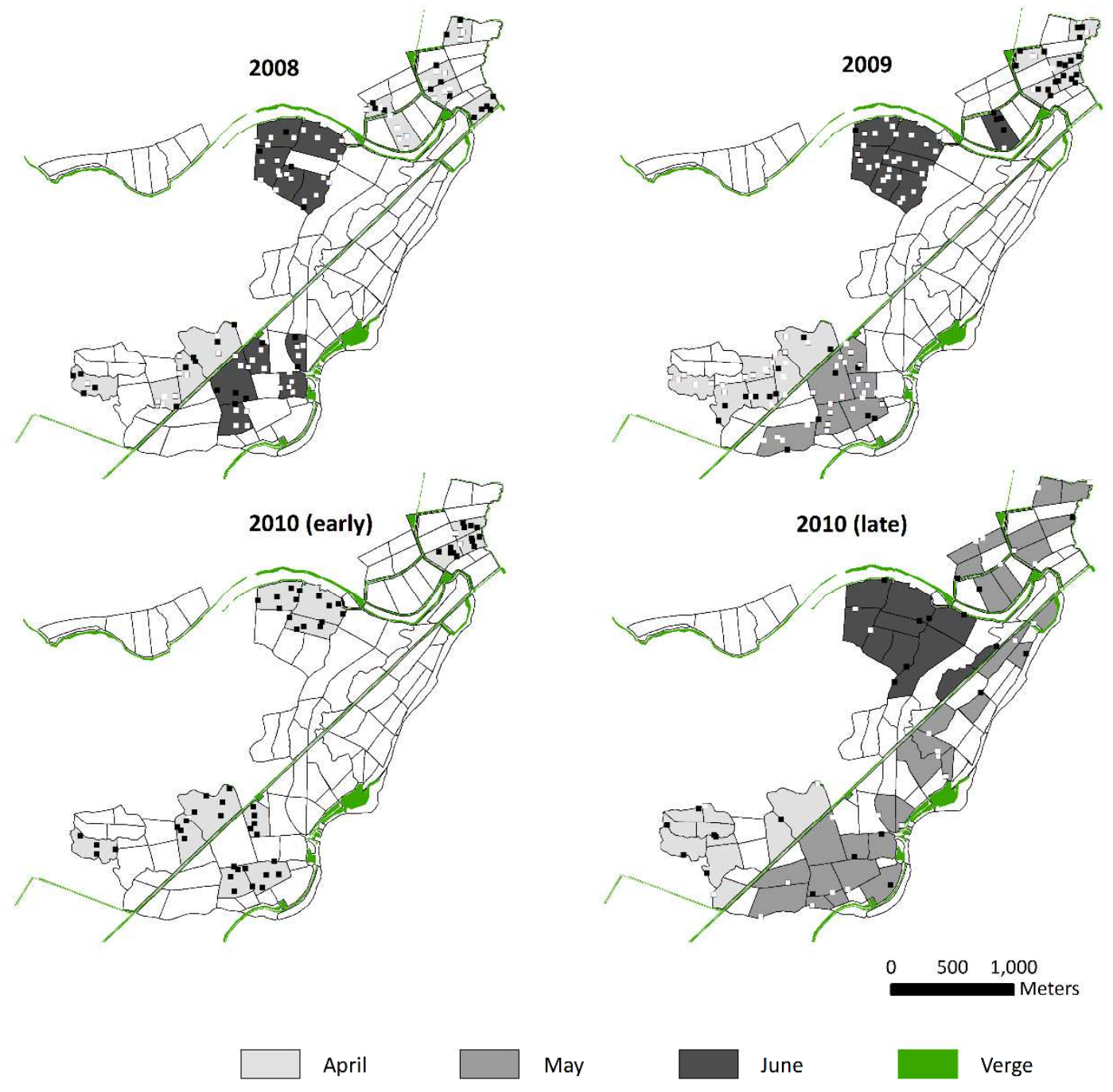

